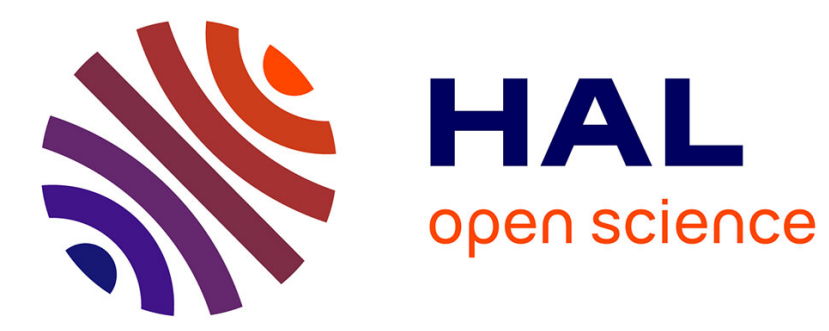

\title{
Nanosized Si/C/N composite powders formed by laser-aerosol coupling
}

N. Herlin, O. Croix, M. Cauchetier, M. Luce, E. Musset

\section{To cite this version:}

N. Herlin, O. Croix, M. Cauchetier, M. Luce, E. Musset. Nanosized Si/C/N composite powders formed by laser-aerosol coupling. Journal de Physique IV Proceedings, 1993, 03 (C7), pp.C7-1481-C7-1484. 10.1051/jp4:19937232 . jpa-00251869

\section{HAL Id: jpa-00251869 https://hal.science/jpa-00251869}

Submitted on 1 Jan 1993

HAL is a multi-disciplinary open access archive for the deposit and dissemination of scientific research documents, whether they are published or not. The documents may come from teaching and research institutions in France or abroad, or from public or private research centers.
L'archive ouverte pluridisciplinaire HAL, est destinée au dépôt et à la diffusion de documents scientifiques de niveau recherche, publiés ou non, émanant des établissements d'enseignement et de recherche français ou étrangers, des laboratoires publics ou privés. 


\title{
Nanosized $\mathrm{Si} / \mathrm{C} / \mathrm{N}$ composite powders formed by laser-aerosol coupling
}

\author{
N. HERLIN, O. CROIX, M. CAUCHETIER, M. LUCE and E. MUSSET
}

CEA-DSM-DRECAM, Service des Photons, Atomes et Molécules, CE Saclay, 91191 Gif-sur-Yvette cedex, France

\begin{abstract}
Recently it has been shown that ultrafine preceramic $\mathrm{Si} / \mathrm{C} / \mathrm{N}$ powders in the nanometric range can be obtained by combining the ultrasonic injection of a liquid precursor with the $\mathrm{CO}_{2}$ laser irradiation. At the CEA the first experiments were conducted with hexamethyldisilazane - $\left(\mathrm{CH}_{3}\right)_{3} \mathrm{SiNHSi}\left(\mathrm{CH}_{3}\right)_{3}$ - (or HMDS) as the precursor.The aerosol droplets formed by the Pyrosol process are carried out with a flow of argon or argon ammonia mixture into the beam of a high powered industrial continuous wave $\mathrm{CO}_{2}$ laser. At laboratory scale up to $100 \mathrm{~cm}^{3} / \mathrm{hr}$ of liquid are displaced with a conversion efficiency (liquid $\rightarrow$ powder) of about $45 \%$. The chemical composition is controlled by varying the synthesis conditions. The $\mathrm{C} / \mathrm{N}$ atomic ratio changes from 3 (under argon) to 0.35 (under argon + ammonia). The as-formed powders are amorphous, monodispersed and nanosized $(<100 \mathrm{~nm})$. The effect of heating under nitrogen atmosphere has been studied by various diagnostics (chemical analysis, BET, XRD).
\end{abstract}

\section{INTRODUCTION.}

Materials with novel properties are obtained when the constituant phase morphology is reduced to nanometer dimensions (1). A significant improvement in thermomechanical properties can be achieved by the use of homogeneous nanophase powders for various compositional systems (for example, $\mathrm{Si} / \mathrm{C} / \mathrm{N}$ ). The growing interest in $\mathrm{Si} / \mathrm{C} / \mathrm{N}$ nanocomposite ceramics is also explained by their large range of properties from superplastic to a high strength and toughness, depending on the composition (2). The performances of the final products are strongly affected by the properties of the original powders, therefore the synthesis of such powders must be carefully controlled. In this respect, the laser - induced synthesis appears as ideal. The reactions are conducted in a confined, well defined wall-less zone having rapid and cooling rates and occuring with fast reaction time which can be controlled by varying the flow rates of the reactant gases or the reactor pressure. Silane has been the most extensively used precursor 
in laser production of $\mathrm{Si}$ - based ceramic powders. But it remains too expensive and hazardous to scale up the process and recently, nitrogeneous organosilicon compounds are preferred (3).

This paper reports the synthesis of $\mathrm{Si} / \mathrm{C} / \mathrm{N}$ powders using hexamethyldisilazane (HMDS) injected in the aerosol form into the beam of a high powered $\mathrm{CO}_{2}$ laser which is strongly absorbed by the aerosol.

\section{EXPERIMENTAL.}

The experimental device is shown on the Figure 1 and has been described elsewhere (4). The aerosol droplets are generated by a piezoelectric transducer placed in a glass jar (Pyrosol 7901 model from $\mathrm{RBI}$ ) and carried out into the expanded beam (X2) of a high powered $\mathrm{CO}_{2}$ industrial laser (CILAS CI1000). The powders are collected in a glass chamber equipped with a cylindrical metallic filter heated at about $120^{\circ} \mathrm{C}$. Heating treatments under flowing nitrogen are performed at atmospheric pressure in a high temperature graphite furnace (model GE80 from Pyrox) at various temperatures between 1000 and $1600^{\circ} \mathrm{C}$. Different methods are used to characterize the as-formed and the annealed powders : chemical analysis, IR spectroscopy, X-ray diffraction, BET method and TEM.

\section{RESULTS AND DISCUSSION}

\subsection{Laser synthesis.}

Table I presents the main parameters of the synthesis for a laser power of $600 \mathrm{~W}$ and the production results with the chemical analysis and the determination of the specific surface area $\left(\mathrm{S}_{\mathrm{BET}}\right)$.

\begin{tabular}{|c|c|c|c|c|c|c|c|c|c|c|}
\hline \multirow[t]{2}{*}{ Run } & \multicolumn{2}{|c|}{$\begin{array}{l}\text { Carrier gas flow } \\
\text { rates }\left(\mathrm{cm}^{3} / \mathrm{min}\right)\end{array}$} & \multirow[t]{2}{*}{$\begin{array}{l}\text { Duration } \\
\text { (min) }\end{array}$} & \multirow[t]{2}{*}{$\begin{array}{l}\text { Production } \\
\text { yield }(\mathrm{g} / \mathrm{hr})\end{array}$} & \multirow[t]{2}{*}{$\begin{array}{l}\text { Conversion } \\
\text { rate }(\%)\end{array}$} & \multicolumn{3}{|c|}{$\begin{array}{c}\text { Chemical analysis } \\
(w t \%)\end{array}$} & \multirow{2}{*}{$\begin{array}{l}\mathrm{C} / \mathrm{N} \\
\text { atomic } \\
\text { ratio }\end{array}$} & \multirow[t]{2}{*}{$\begin{array}{l}\mathrm{SBET} \\
\left(\mathrm{m}^{2} / \mathrm{g}\right)\end{array}$} \\
\hline & Argon & $\mathrm{NH}_{3}$ & & & & C & $\mathrm{N}$ & 0 & & \\
\hline $03^{a}$ & 2000 & 0 & 54 & 20.8 & n.m. & 29.9 & 11.6 & 6.8 & 3.0 & 133 \\
\hline $06^{\mathrm{a}}$ & 1200 & 620 & 32 & 14.8 & $\mathrm{n} . \mathrm{m}$. & 6.7 & 22.5 & 18.0 & 0.35 & 136 \\
\hline $22^{\mathrm{a}}$ & 1900 & 0 & 28 & 22 & 34 & 28 & 13 & 9.0 & 2.2 & 139 \\
\hline $28^{b}$ & 2640 & 0 & 59 & 38 & 46 & 30 & 12 & 6.0 & 2.5 & 88 \\
\hline $29 \mathrm{~b}$ & 2660 & 275 & 63 & 30 & 39 & 24 & 17 & 8.0 & 1.4 & 167 \\
\hline $31^{b}$ & 2080 & 725 & 74 & 28 & 44 & 19 & 23 & 6.0 & 0.8 & 116 \\
\hline $32^{b}$ & 2660 & 140 & 75 & 28 & 44 & 25 & 18 & 7.0 & 1.4 & 95 \\
\hline
\end{tabular}

$\mathrm{a}:$ inlet diameter $=9 \mathrm{~mm} ;{ }^{b}:$ inlet diameter $=13 \mathrm{~mm} ; \mathrm{n} \cdot \mathrm{m} .=$ not measured.

TABLE I. Synthesis conditions and chemical analysis results.

Up to $100 \mathrm{~cm}^{3} / \mathrm{hr}$ of liquid have been displaced (Run28) with a conversion efficiency (liquid $\rightarrow$ powder) of $46 \%$. The current experiment is stable for more than one hour and sufficient powder quantities have been collected to perform characterizations on the as-formed powders and to follow the evolution of the structure after annealing experiments.

From chemical analysis its appears that the $(\mathrm{Si}+\mathrm{H})$ content remains about constant near $50 \%$. The Nrich powders are more sensitive to the oxidation and the $\mathrm{O}$ content can be high, the powders being handled in air without any special care.

The color of the powders varyes from black or grey for a $\mathrm{C}$-rich powder which contains an excess of free carbon to yellow or ivory for a $\mathrm{N}$-rich powder, identical to a $\mathrm{Si}_{3} \mathrm{~N}_{4}$ powder prepared by laser pyrolysis of a $\mathrm{SiH}_{4}-\mathrm{NH}_{3}$ mixture.

The as-formed powders are amorphous through X-ray diffraction analysis. TEM observations reveal a monodispersion in the particle size centered below $100 \mathrm{~nm}$ as shown on the Figure 2 . The TEM results are confirmed by the high specific surface areas (generally $>100 \mathrm{~m}^{2} / \mathrm{g}$ ) obtained by the BET method. IR spectroscopy on the as-prepared powders has been previously reported (4) and shows the presence of $\mathrm{N}-\mathrm{H}, \mathrm{Si}-\mathrm{H}, \mathrm{C}-\mathrm{H}$ and $\mathrm{Si}-\mathrm{CH}_{3}$ bonds with a broad band between 1100 and $800 \mathrm{~cm}^{-1}$ which is usually 
attributed to $\mathrm{Si}-\mathrm{C}, \mathrm{Si}-\mathrm{O}$ and $\mathrm{Si}-\mathrm{N}$ bonds. The $\mathrm{N}$-rich powders present a band in the $460 \mathrm{~cm}^{-1}$ region attributed to the $\mathrm{Si}-\mathrm{N}$ bond.

\subsection{Annealing treatments.}

Up to $1000^{\circ} \mathrm{C}$ the weight loss between 2 and $8 \%$ is essentially due to the evolution of hydrogenated compounds: $\mathrm{CH}_{4}, \mathrm{H}_{2} \mathrm{O}$ or $\mathrm{NH}_{3}$ (4). Figure 3 shows the evolution under a nitrogen atmosphere of the weight per chemical element ( $\mathrm{Si}, \mathrm{C}, \mathrm{N}$ and $\mathrm{O}$ ) as a function of the annealing temperature, supposing an initial weight of $1000 \mathrm{mg}$. These measurements are consistent with the observations obtained by other methods and reported elsewhere $(4,5)$. Between 1000 and $1400^{\circ} \mathrm{C}$ the weight of nitrogen increases indicating an activity of $\mathrm{N}$ atoms on the powder. Then the nitrogened phases become unstable and decompose with evolution of $\mathrm{N}_{2}$ as shown on the TG-MS analysis curves (4). At higher temperature the powder which has remained amorphous up to $1400^{\circ} \mathrm{C}$ is very well crystallized as shown on the Figure 4 for the powder HMDS03. On the XRD pattern the cubic $\beta$-SiC phase and the $2 \mathrm{H}-\mathrm{SiC}$ phase (an $\alpha$-SiC polytype) are unambiguously identified.

An identical annealing treatment for a N-rich powder (HMDS06) leads only to the formation of $\alpha$ $\mathrm{Si}_{3} \mathrm{~N}_{4}$ as shown also on the Figure 4.

Other recent results on the characterizations of the annealed powders have been reported $(4,5)$ and an interesting zone appears in the $1400-1500^{\circ} \mathrm{C}$ region where occurs the amorphous $\rightarrow$ crystalline morphology change. Elaborated characterization methods such as MAS-NMR of ${ }^{29} \mathrm{Si}$, XPS, EXAFS or neutron diffusion will be needed with the aim to identify the amorphous phases.

\section{CONCLUSION.}

It has been shown that the coupling between an aerosol of a $\mathrm{Si} / \mathrm{C} / \mathrm{N}$ liquid precursor and the $\mathrm{CO}_{2}$ laser irradiation is a new route to obtain nanocomposite ceramic powders. Further studies will be concerned by sintering experiments which will need powders in relative high amounts. It is necessary to increase the production and the yield of the synthesis reactions and to find other low cost liquid precursors with higher Si-content but more viscous to scale up the process.

This work was supported by the CEC Brite - Euram contract $n^{\circ} 90$ - BE4236 "Cost effective laser synthesized nanoscale powders and cases of thermomecanichal applications".

\section{REFERENCES.}

(1). R.DAGANI, "Nanostructured materials promise to advance range of technologies", Ch. and Eng.News, pp.18-24, Nov.23, 1992.

(2). K.NIIHARA and K.NAKAHIRA, "Strengthening and toughening mechanims in nanocomposite ceramics", Ann.Chim.Fr. 16, 479-86 (1991).

(3). K.E.GONSALVES, P.R.STRUTT, T.D.XIAO and P.G.KLEMENS, "Synthesis of Si(C,N) nanoparticles by rapid laser polycondensation/crosslinking reactions of an organosilazane precursor", J.Mater.Sc. 27(12) 3231-38 (1992).

(4). M.CAUCHETIER, O.CROIX, N.HERLIN and M.LUCE, "Nanocomposite Si/C/N powders production by laser - aerosol interaction". Submitted to the J.Am.Ceram.Soc.

(5). N.HERLIN, M.LUCE, E.MUSSET and M.CAUCHETIER, "Synthesis and characterization of nanocomposite $\mathrm{Si} / \mathrm{C} / \mathrm{N}$ powders by laser spray pyrolysis of hexamethyldisilazane". Submitted to the J.Eur.Ceram.Soc. 


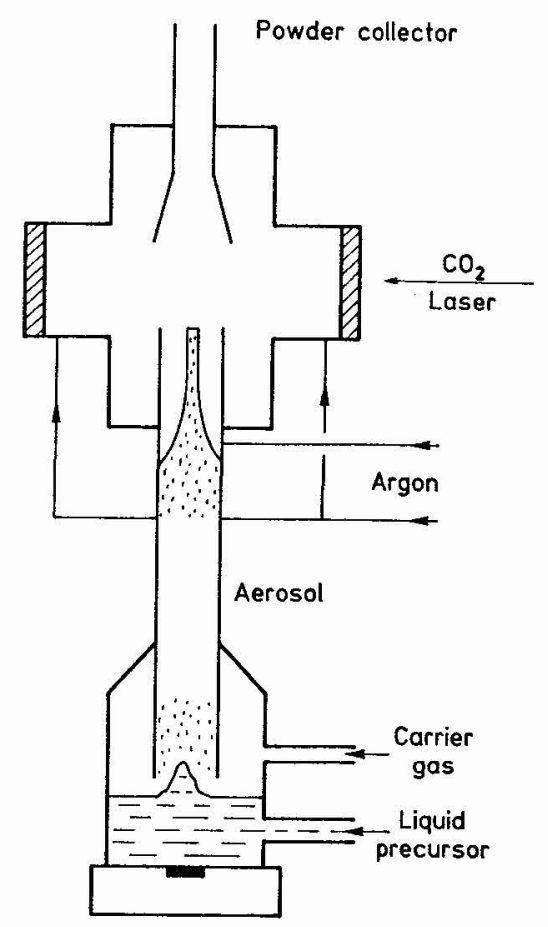

FIGURE 1. Schematic of the laser - aerosol coupling.

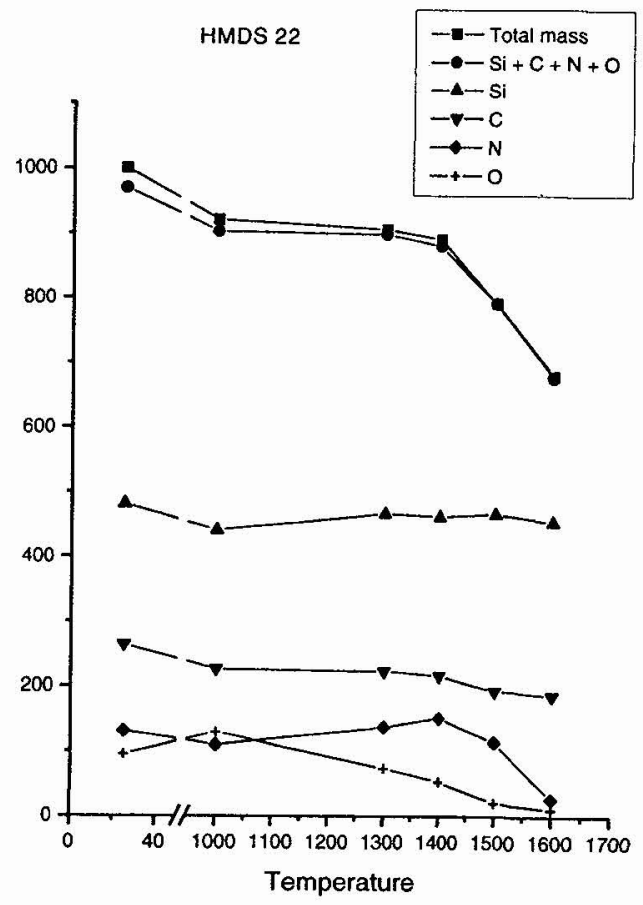

FIGURE 3. Evolution of the chemical composition during annealing.

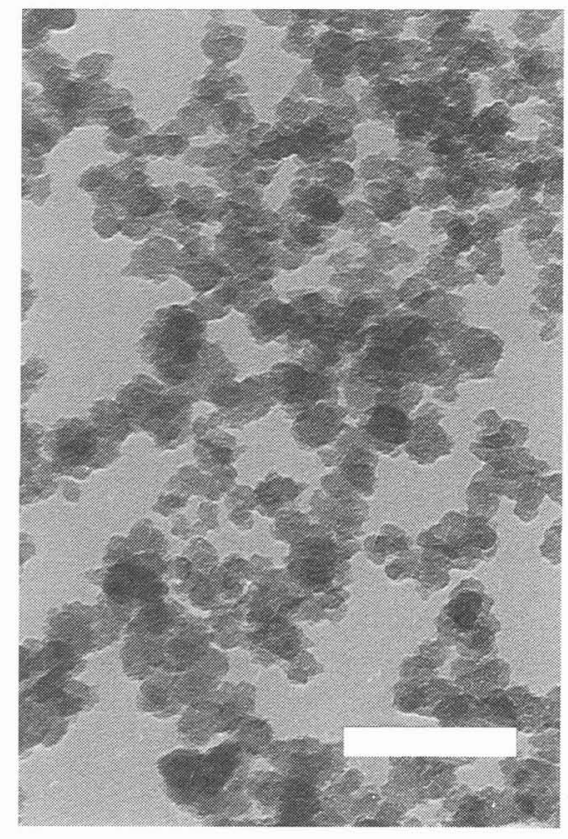

FIGURE 2. Microphotograph of an as - formed powder (bar $=100 \mathrm{~nm}$ ).
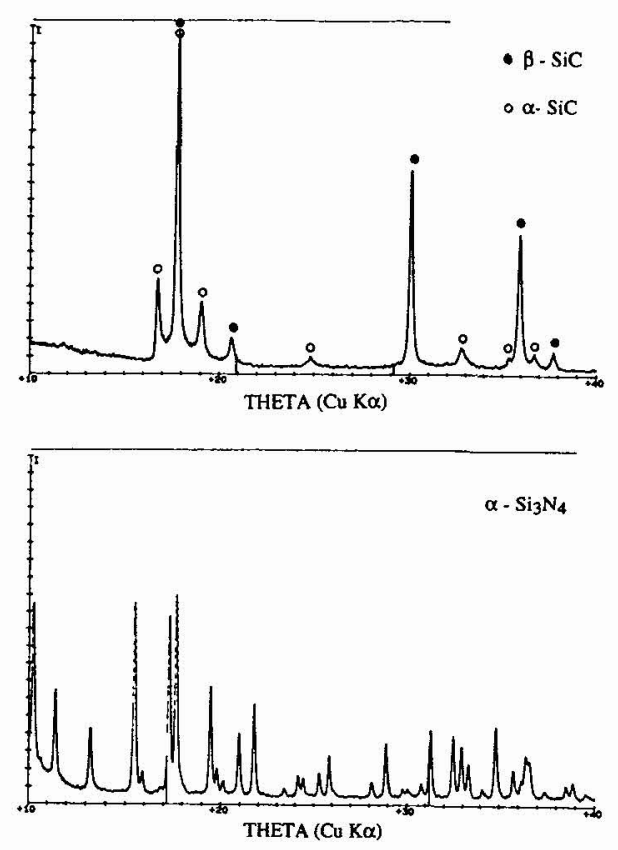

FIGURE 4. XRD patterns of annealed powders : C-rich (top); N-rich (bottom). 